\title{
Rural workload: study performed in two rural environments in the state of Rio Grande do Sul, Brazil
}

\author{
Carga de trabalho rural: estudo desenvolvido em dois ambientes \\ rurais do Estado do Rio Grande do Sul, Brasil
}

\author{
Laurelize Pereira Rocha ${ }^{\mathrm{I}}$ Anelise Miritz Borges ${ }^{\mathrm{I}}$ Clarice Alves Bonow \\ Marlise Capa Verde de Almeida ${ }^{I}$ Diéssica Roggia Piexak ${ }^{\mathrm{I}}$ Marta Regina Cezar-Vaz ${ }^{\mathrm{I}}$
}

\section{ABSTRACT}

This study aimed to analyze loads resulting from the rural work of fruit and vegetable farmers. This exploratory and descriptive study was conducted with 259 farm workers from two rural environments. A semi-structured questionnaire based on the concepts of NASA-TLX was used to assess workload. The male and female workers of one environment reported that the demand that contributed the most to their workload was the level of total effort, while the women of the other environment reported that the physical demand was more relevant for WL. In conclusion, evidence concerning workload supports further investigation into the health of rural workers and the development of preventive strategies related to rural work.

Key words: rural health, occupational health, workload.

\section{RESUMO}

Este estudo objetivou analisar as cargas decorrentes do trabalho rural de agricultores hortifrutigranjeiros. Realizou se estudo exploratório e descritivo, com 259 agricultores hortifrutigranjeiros em dois ambientes rurais. Utilizou-se questionário semiestruturado, baseado nos conceitos do instrumento NASA-TLX, para analisar a carga de trabalho. Os resultados mostraram que, para os agricultores homens e para as mulheres de um ambiente, a demanda que mais contribui para a formação da carga de trabalho foi o nivel de esforço total; para mulheres do outro ambiente, foi exigência fisica. Concluise que as evidências relativas à carga de trabalho fornecem subsidios para outras investigações da saúde da população rural e para o desenvolvimento de estratégias de prevenção de agravos relacionados ao trabalho rural.

Palavras-chave: saúde da população rural, saúde do trabalhador, carga de trabalho.

\section{INTRODUCTION}

The workload (WL) experienced by workers results from the interaction between human's biopsychological capacity and demands inherent to environmental conditions, work organization, and task, which can affect workers' health-disease continuum leading to physical and psychological disorders (SECCO et al., 2011). WL can be defined as a tensional, mental and/or physical reflex that results from the relationship between a tasks's operational demands and environmental conditions with the workers' capacity to perform such tasks. This reflex can manifest in fatigue, stress, diseases and occupational accidents (HART, 2006). Therefore, WL results from the inter-relationship of work components. For each occupational situation, there will be a conflict between the demands imposed by the task and the worker's biopsychological capacity to meet these demands. Among the numerous professions, farming is highlited, because it includes arduous tasks, demanding energy from human capacities such as muscle strength, awkward postures, long periods of time exposed to stressful working and environmental conditions, fast-paced work, repetitiveness, machinery using and work tools, among others. Such conditions expose workers to continuous workloads with the potential to generate injuries, disease, and occupational diseases (ILO, 2010). In this context, the

\footnotetext{
IEscola de Enfermagem, Universidade Federal do Rio Grande (FURG), 962000-400, Rio Grande, RS, Brasil. E-mail: cezarvaz@vetorial.net. *Corresponding author

IIFaculdade de Enfermagem, Universidade Federal de Pelotas (UFPEL), Pelotas, RS, Brasil. 
need to understand agricultural work and consider its influence on workers health of is the key to establish a link among health, work and disease.

Therefore, this study is justified by the need to measure WL experienced by farm workers, as well as by the need to develop strategies to prevent diseases and reduce occupational accidents given the productive importance of this work to society and the relevance of considering the experiences of these workers. Hence, this study aimed to analyze loads accruing from the rural work of farm workers.

\section{MATERIALS AND METHODS}

This exploratory and descriptive study was conducted in two rural environments in Rio Grande do Sul, RS, Brazil: environment 1 (EI) is located in the extreme south and environment 2 (EII) is located in extreme east. EI is considered location of historical heritage due to its vegetal diversity and EII is a border region. These two regions were chosen because they are geographically opposite in the interior of RS (Figure 1). Although these regions are geographically apart, the farmers of both areas are small producers with up to 50 hectares of land (BRASIL, 2006), they grow fruits and vegetables (lettuce, tomato, arugula, strawberry, orange, pumpkin) and use similar work equipment such as: rakes, watering pots, shovels and hoes. It is known that the existence of geo-cultural characteristics contributes to similarities or diversities among farm workers; however, our choice was not based on cultural elements but on characteristics related to the workload experienced.

The study was approved by the Institutional Review Board at the Universidade Federal de Rio Grande (Protocol No. 026/2013). All the study participants received clarification concerning the study's objectives and signed two copies of free and informed consent forms. Confidentiality of the participants' information was ensured.

Because data regarding the total population of farm workers were not provided by official agencies such as the Instituto Brasileiro de Geografia e Estatística, the sample was based on the total number of inhabitants in rural areas using StatCalc from the EpiInfo software version 3.5.2, employing the following parameters: unknown prevalence of phenomena and $95 \%$ of confidence interval. Based on these, it was obtained a sample of 369 subjects: 179 for EI and 190 for EII.

Data were collected from March to October 2013 and the subjects were selected according to the following criteria: farm workers living in the rural areas EI and EII; being 18 years old or older; directly working with horticultural agriculture, even if on a subsistence basis. Workers who did not perform agricultural tasks in the period of data collection were excluded. A total of 259 farm workers participated in the study: 129 from EI and 130 from EII. There were a total of 26 refusals and 36 losses; the losses occurred after at least five attempts to contact the individuals at home in different week days. Data collection started by applying a semi-structured questionnaire based on the NASA-TLX to assess WL. Sections regarding the profile of farm workers were used to develop this study based on the variables: city, age, sex, and schooling (complete years). The characterization of the work developed by farm workers included the variables: daily working hours in agriculture, experience with the agricultural work, size of the farming area, and assessment of WL. The WL was assessed through an interview using the NASATLX, an instrument developed by the National Aeronautics and Space Administration (NASA), which provides a WL index. It is a multidimensional instrument that predicts an overall score based on a weighted mean that assesses six demands: mental, physical, temporal, total effort, performance, and frustration demands. Three dimensions refer to aspects or demands attributed by the subject (mental, physical and temporal), while the other three refer to the interaction of the individual with tasks (effort, frustration, and performance) (HART, 2006).

The NASA-TLX provides an overall quantitative assessment of WL based on the assessment of six dimensions, presented and explained to the study participants, according to their definitions, and adapted to the context: Mental Demand: how much mental activity is required to perform the task? (e.g., thinking, choosing, calculating, deciding, etc.); Physical demand: How much physical activity is required? Is the task easy or demanding? (e.g., pushing, pulling, carrying, weeding, etc.); Temporal Demand: How do you feel in regard to the time available to complete the task? Do you feel pressured to finish the task? Is the pace slow or fast? Performance: How successful do you consider yourself to be in accomplishing the tasks? Is your performance as skilled as before; was it poorer or better? Effort: How hard do you have to work to accomplish your activities? Are they difficult for your physical and mental state or can you perform them with ease, without much effort? Frustration level: How motivated, satisfied, or discouraged, irritated and stressed do you feel? 


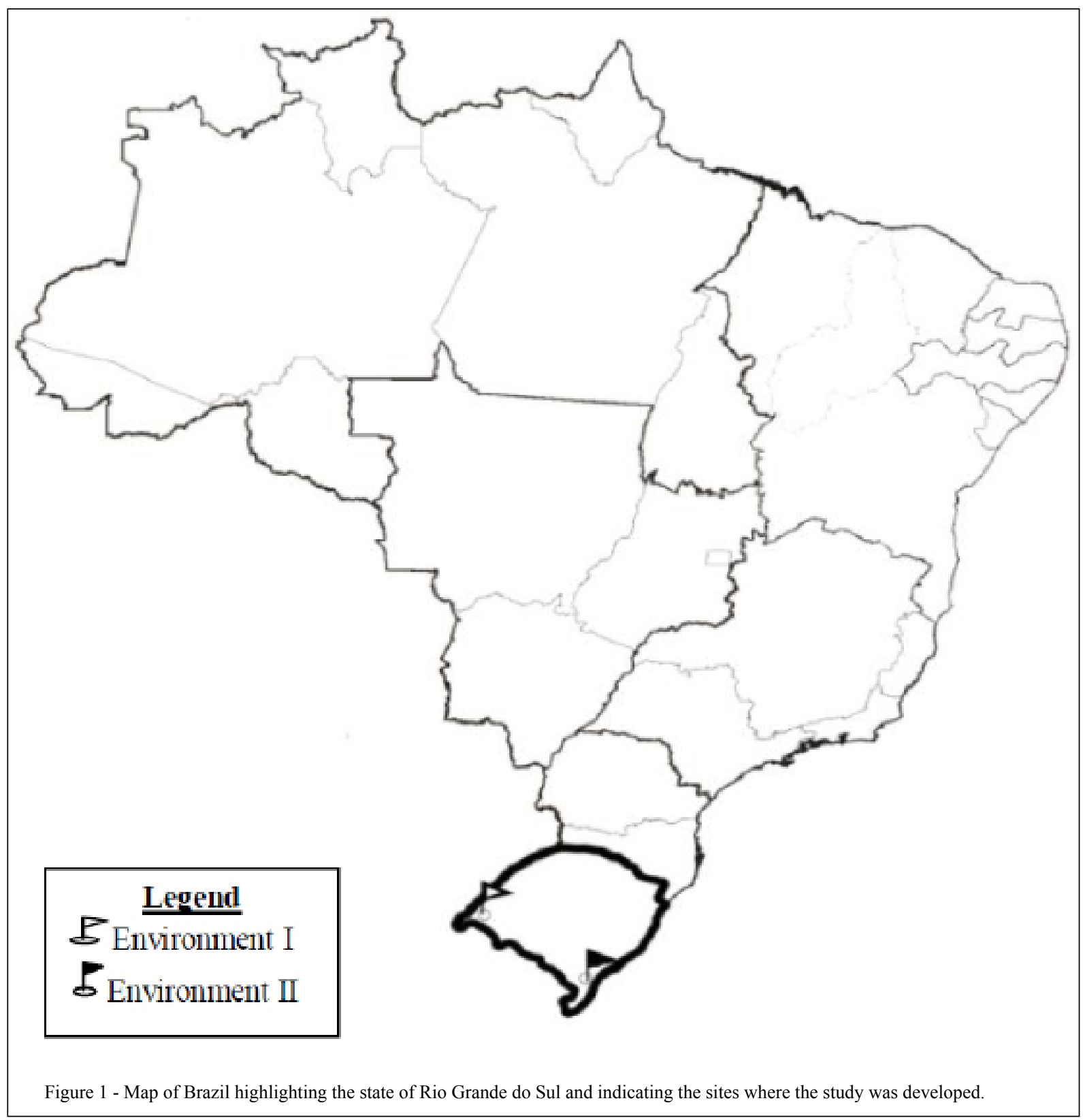

The WL assessment procedure involves two stages. The first is composed of a continuous, non-numeric scale of 20 points, closed at both ends. End anchors (low and high) are given so that the workers can choose the level that corresponds to the demand that contributes the most to WL, i.e., the WL magnitude/intensity. Therefore, values lower than ten represent a low LT index, while values greater than ten represent a high LT index. The closer the number to 20, the higher the WL (HART, 2006). In the second stage, 15 different pairs of demands combined are presented to the participants. The demands can be selected five times or none. The interviewees identify the most important demand from each pair, the one that contributes the most to WL. The demand considered to be relevant will weight in the overall WL computation, qualifying the scale in terms of its sensitivity (HART, 2006). This instrument was chosen because it is broad and comprises six demands (mental, physical, temporal, effort, frustration, and performance). Another instrument that could be used to assess workload is the SWAT 
(Subjective Workload Assessment Technique), however, it only presents three dimensions (temporal, mental effort, and stress). For this reason we opted to use the NASA-TLX (CARDOSO, GONTIJO, 2012). Additionally, one study addressing WL measurement using questionnaires indicates that the NASA-TLX is more frequently used than the SWAT, for instance (WINTER, 2014), thus influencing our choice. Furthermore, repeating the questionnaire's applicability strengthens comparisons among different studies addressing different workers.

Data were double-entered in the Statistical Package for the Social Sciences (SPSS), version 20.0. The weighted mean of demands (ratings x weights) and overall weighted rate of each interviewee was computed for the analysis of WL. Afterwards, data were included in SPSS 20.0 to perform the comparison tests. Therefore, the scores concerning demands obtained with the NASA-TLX were used to quantify subjective WL in the same way the analysis of the individual adjustment of each demand enables understanding the demands that contribute the most to WL. Three participants did not fulfill the second stage of the WL assessment due to the great difficulty they had understanding the instrument. A possible explanation is illiteracy and advanced age. The remaining interviewees had no comprehension problems.

The statistical analysis included descriptive analysis, Levene's test with the variables: WL demands and sex; correlation test (Spearman), considering the variables: WL demands, age, schooling, working time in agriculture, daily working hours, and size of farming area; association test (Pearson's Chi-square test $-\chi^{2}$ ) for the variables: sex, age, daily work hours, and working time in agriculture. For this test, the continuous variables were dichotomized based on the means of each variables. V-Cramer was also calculated to verify the association size effect, considering r-values small effects below 0.3 ; moderate when $0.4<\mathrm{V}$ of Cramer $<0.5$ and large when $r$ was greater than 0.5 ; $p$-value $<0.05$ was adopted to establish statistical significance in all the analyses.

\section{RESULTS}

In regard to the sociodemographic profile: $57.1 \%(n=148)$ of the workers were men and $42.9 \%$ $(n=111)$ were women: In EI $60.5 \%(n=78)$ were men and $39.5 \%(n=51)$ were women; and in EII, 53.8\% $(n=70)$ were men and $46.2 \%(n=60)$ were women. The overall mean age was 51.2 years old, with a standard deviation (SD) of \pm 14.5 . The workers in EI were 55.69 years old $(\mathrm{SD} \pm 13.1)$ and in EII they were 46.8 years old $(\mathrm{SD} \pm 14.6)$, on average. The overall mean of complete years of schooling was 5.35 years $(\mathrm{SD} \pm 3.38)$; in EI, 3.86 years $(\mathrm{SD} \pm 2.36)$ and $\mathrm{EII}$, 6.95 years $(\mathrm{SD} \pm 3.59)$. In regard to how long they were working with agriculture, the mean was 31.4 years $(\mathrm{SD} \pm 19.3)$; in EI, workers reported a mean of 40.6 years $(\mathrm{SD} \pm 15.8)$ and in EII, workers reported a mean of 22.4 years $(\mathrm{SD} \pm 18.2)$. The size of the farming area corresponded to 2.8 hectares (ha) on average ( $\mathrm{SD} \pm 4.1)$, without much variability between the two environments. In regard to daily working hours, the mean was 8.02 hours $(\mathrm{SD} \pm 3.7)$. Table 1 presents the quantification of WL. In general, all the farm workers identified WL as being high (14.8), especially for women in EI (15.2) and men in EII (15.6). The demand that contributed most to overall WL was total effort for male workers of both rural environments and women from EII. The female workers from EI reported that physical demand was

Table 1 - Assessment of workload among horticultural farmers in two rural environments

\begin{tabular}{|c|c|c|c|c|c|c|c|c|}
\hline \multirow{2}{*}{ Horticultural farmers } & \multirow[b]{2}{*}{$\mathrm{N}$} & \multirow[b]{2}{*}{$\mathrm{ME}^{*}$} & \multirow[b]{2}{*}{$\mathrm{PE}^{*}$} & \multirow{2}{*}{$\mathrm{TP}^{*}$} & \multirow{2}{*}{$\begin{array}{c}\text { oad den } \\
\text { OP* }^{*}\end{array}$} & \multirow[b]{2}{*}{$\mathrm{TE}^{*}$} & \multirow[b]{2}{*}{$\mathrm{FR}^{*}$} & \multirow[b]{2}{*}{ OW } \\
\hline & & & & & & & & \\
\hline EI & 128 & 26.72 & 51.52 & 33.96 & 29.46 & 51.84 & 23.38 & 14.50 \\
\hline Women & 51 & 28.33 & 56.27 & 32.41 & 29.06 & 55.76 & 25.63 & 15.16 \\
\hline Men & 77 & 25.65 & 48.53 & 34.99 & 29.73 & 49.25 & 21.90 & 14.05 \\
\hline EII & 128 & 22.04 & 51.76 & 38.95 & 37.84 & 53.63 & 22.56 & 15.11 \\
\hline Women & 60 & 22.02 & 50.15 & 32.63 & 36.13 & 52.17 & 25.75 & 14.58 \\
\hline Men & 68 & 22.06 & 53.18 & 44.51 & 39.35 & 54.93 & 19.75 & 15.59 \\
\hline EI/ EII & 256 & 24.38 & 51.69 & 36.45 & 33.65 & 52.74 & 22.97 & 14.80 \\
\hline
\end{tabular}

*Workload: ME (Mental Effort); PE (Physical Effort); TP (Time Pressure); OP (Own Performance); TE (Total Effort); FR (Frustration); OW (Overall Workload). 
what contributed the most for WL, with 56.3. The explanation for this finding may be the age of the female workers from EI, who presented an average age of 54.7 years old, while the female workers from EII were 44.8 years old on average.

A statistically significant difference was found between the mean concerning temporal demand, which was higher for men $(t(256)=39.5$, $\mathrm{SD}=27.12)$ than for women $(t(256)=32.5$, $\mathrm{SD} \pm 25.87)$. The variances for the remaining demands and overall WL are almost the same among the male and female workers.

Analysis presented in table 2 showed correlations between WL demand and the WL overall rating with sociodemograhic variables and variables concerning work characteristics. Therefore, one finding is that the older the worker, the less they acknowledges TE, FR and OW and vice-versa. In regard to schooling, the higher the level of education, the less one acknowledges ME and vice-versa, and the more one acknowledges TP for the performance of work and vice-versa. The variable time working in agriculture showed that the more experience one has working in agriculture, the less one acknowledges TP and OW, and vice-versa. For the variables daily working hours, we verified, based on the reports of the farm workers, that the more hours worked on a daily basis, the higher the mental, temporal and overall WL experienced.

\section{DISCUSSION}

The sociodemographic characteristic of workers from both rural environments in RS, Brazil, showed that this is a population with a higher proportion of men, in general having a high average age and low educational level. Data regarding schooling reveal that the problem of low educational level still persists among the rural population (FARIA et al., 2006).

In regard to the characteristics of work, we verified that these workers present a high average (31.37 years) of time working in farming and work eight hours daily, on average, in farming activity. An average of 39.7 hours per week was verified in the state of Rio Grande do Sul in 2007, which is similar to the total hours worked by both rural and urban workers (IPEA, 2009), and is also similar to this study's findings. We note that the daily time spent in farming work is positively and significantly correlated with the mental and total effort demands, and is also positively correlated with overall WL; i.e., the more hours one works, the higher the WL. These findings can guide future interventions concerning WL being related to diseases in this specific group. The reason is that horticultural farmers perform strenuous work (NCFH, 2013), which can lead to physical harm, such as musculoskeletal lesions, considered one the most severe health problems among farm workers in the United Kingdom, Holland and France (EU-OSHA, 2012).

Considering the results, overall WL presented a high index among horticultural workers, an aspect that showed WL is acknowledged by the workers and the importance they attribute to demands. Assessing WL includes measuring how much physical, physiological, cognitive and psychological effort is required for workers to perform their tasks. Therefore, assessing WL is essential to quantifying the workers' subjective perceptions in regard to the capacity they have to perform tasks, which enables determining preventive measures against physical and mental fatigue, temporal demands and diseases and accidents accruing from these (YOUNG et al., 2008).

The demand (level of total effort), which comprises level of mental and physical effort, was

Table 2 - Correlations (Spearman's $\rho$ ) and p-value among workload demands, overal workload and sociodemograohic and work characteristics.

\begin{tabular}{|c|c|c|c|c|c|c|c|}
\hline & $\mathrm{ME}^{*}$ & $P E^{*}$ & $\mathrm{TP}^{*}$ & $\mathrm{OP}^{*}$ & $\mathrm{TE}^{*}$ & $\mathrm{FR}^{*}$ & $\mathrm{OW}^{*}$ \\
\hline Age & - & - & - & - & $-0.180(0.004)$ & $-0.141(0.024)$ & $-0.288(0.001)$ \\
\hline Schooling & $-0.184(0.005)$ & - & $0.197(0.003)$ & - & - & - & - \\
\hline $\begin{array}{l}\text { Experience with agricultural } \\
\text { work }\end{array}$ & - & - & $\begin{array}{l}-0.149 \\
(0.019)\end{array}$ & - & - & - & $-0.241(0.001)$ \\
\hline Daily working hours & $0.125(0.047)$ & - & $0.234(0.001)$ & - & - & - & $0.287(0.001)$ \\
\hline Size of the farming area & - & - & - & - & - & - & - \\
\hline
\end{tabular}

*Workload: ME (Mental Effort); PE (Physical Effort); TP (Time Pressure); OP (Own Performance); TE (Total Effort); FR (Frustration); OW (Overall Workload). 
the most frequently reported by workers as being the most relevant for WL. This issue is considered in the assessment of one's capacity for work, as mental load influences physical load (ROJA et al., 2009). It is important to note that physical effort, as previously mentioned, is very intense in agricultural work, since planting, harvesting, and preparing the soil, is mainly performed using simple and manual tools (e.g., shovel, hoe), which do not minimize physical effort, but rather increase it. Mental effort is also present due to the work characteristics, as in order to plant and prepare the soil, the farmer has to plan not only using previous knowledge, but also decide on which changes are necessary based on the work itself, climate, and economic issues, such as total cost of planting.

When comparing male and female farm workers, the latter in EI reported that physical demand was the most relevant for overall WL. It shows that these women in particular, identify the agricultural tasks they perform as being more physically demanding compared to other demands (mental, temporal, total effort, performance and frustration). The women from the other rural environment did not assign such a level of importance to this specific demand, which may be explained by differences of age. Those women reporting that physical effort was more important were 54.7 years old on average while women from EII were 44.8 years old on average. Additionally, other aspects may have contributed to this difference such as the involvement of female farmworkers with house chores that result in physical overload, a fact acknowledged by the literature (STADUTO et al., 2013). Another study also identified physical demand as being the most relevant for WL, showing this is related to daily working hours, postures required by the tasks, physical fatigue and work overload (BALLARDIN \& GUIMARÃES, 2009). In this study, physical demand was positively correlated with daily working hours, that is, there is a tendency of workers to report that increased working hours increase mental WL.

WL was also negatively correlated with age, showing the older an individual the lower his/ her perception of overall WL and vice-versa. This is expected as younger farmworkers recognize higher levels of WL than older farmworkers. The relationship between WL and age is well established in the literature (KULLOK, 2014), as there is a point in which a biological marker signalizes the body's natural tendency to wear out due to the exposure of farmworkers over the course of life.

WL under study is a way to measure how much load workers can bear since the farming work imposes many physical demands such as planting, harvesting, and preparing the soil. Additionally, it demands workers to perform tasks daily (temporal), plan the production (mental demand), perform a quality work (performance), present leadership and organization (total effort), and deal well with the instability of this activity, e.g. there is not a steady income (frustration).

\section{CONCLUSION}

This WL analysis enabled verifying that the horticultural farmers under study acknowledge they experience high WL and specifically report that "total effort" is the most relevant demand contributing for increased WL. Some correlations between WL and sociodemographic variables and work variables were statistically significant: age, schooling, experience with agricultural work, and daily working hours. Therefore, after measuring WL, we propose that healthcare facilities work together with rural workers associations using information concerning WL to develop feasible alternatives. This type of joint work needs to approximate the routine life of farmworkers with rural workers organizations to ensure a longitudinal transformation of the relationship between working conditions and WL.

\section{BIOETHICS AND BIOSSECURITY COMMITTEE APPROVAL}

026/2013.

Process: 23116.000645/2013-73, report No.

\section{ACKNOWLEDGEMENTS}

Thanks to Conselho Nacional de Desenvolvimento Científico e Tecnológico (CNPq) (process n. 405285/2012-4) by financial support.

\section{REFERENCES}

BALLARDIN, L.; GUIMARÃES, L.B.M. Evaluation of na oil distributor company operator's workload. Produção, v.19, p.581592, 2009.

BRASIL. Lei $\mathbf{n}^{\mathbf{0}}$ 11.428, de 22 de dezembro de 2006. Dispõe sobre a utilização da vegetação nativa do Bioma Mata Atlântica, e dá outras providências. Available from: $<$ http://www.planalto. gov.br/ccivil_03/_ato2004-2006/2006/lei/111428.htm>. Accessed: Jul. $\overline{18}, 2 \overline{0} 15$.

CARDOSO, M.S.; GONTIJO, L.A. Evaluation of mental workload and performance measurement: NASA TLX and SWAT. Gestão \& Produção, v.19, p.873-884, 2012.

EUROPEAN AGENCY FOR SAFETY AND HEALTH AT WORK (EU-OSHA). Musculoskeletal disorders in agriculture. 
In: EASHW, 2012. Available from: <http://osha.europa.eu/en/ sector/agriculture/index_html/msds $>$. Accessed: Dec. 23, 2015.

FARIA, N.M.X. et al. Farm work, dust exposure and respiratory symptoms among farmers. Revista de Saúde Pública, v.40, p.827836, 2006.

HART, S.G. NASA-task load index (NASA-TLX); 20 years later. NASA-Ames Research Center, v.50, p.904-908, 2006.

INTERNATIONAL LABOUR ORGANIZATION (ILO). Code of practice on safety and health in agriculture, 2010. Available from: <http://www.ilo.org/wcmsp5/groups/public/@ed protect/@protrav/@safework/documents/normativeinstrument/ wcms_161135.pdf>. Accessed: Dec. 10, 2014.

INSTITUTO DE PESQUISA ECONÔMICA APLICADA (IPEA) Carga horária de trabalho: evolução e principais mudanças no Brasil. Comunicado da Presidência - n.24, 2009. Available from: $<$ http://www.ppge.ufrgs.br/giacomo/arquivos/eco02268/ipea2009.pdf>. Accessed: Dec. 18, 2014.

KULLOK, A.T. Rural elderly women: the sweat of their bodies and the work of his hands: the paradigms of the Greek polis still present in the current days. Health, v.6, p.292-298, 2014.
NATIONAL CENTER FOR FARMWORKER HEALTH (NCFH). Farmworker Occupational Health and Safety. March, 2013. Available from: <http://www.ncfh.org/docs/fs-Occ\%20Health. pdf $>$. Accessed: Dec. 03, 2014.

ROJA, Z. et al. Assessment of firefighters-rescuers' work severity in relation with interaction between physical and mental load. Proceedings of the Latvian Academy of Sciences. Section B. Natural, Exact, and Applied Sciences, v.63, p.264-70, 2009.

STADUTO, J.A.R. et al. Occupation and income of women and men in rural areas of the State of Parana, Brazil: a gender perspective. Cuadernos de Desarrollo Rural, v.10, p.91-115, 2013.

SECCO, I.A.O. et al. Workloads of external materiality in the nursing team of a teaching hospital in Paraná, Brazil. Ciencia y Enfermería, v.17, p.69-81, 2011.

WINTER, J.C.F. Controversy in human factors constructs and the explosive use of the NASA-TLX: a measurement perspective. Cognition, Technology \& Work, v.16, p.289-297, 2014.

YOUNG, G. et al. Assessment of Workload Using NASA Task Load Index in Perianesthesia Nursing. Journal of PeriAnesthesia Nursing, v.23, p.102-110, 2008. 